\title{
A Phenolic Compound of Endophytic Fungi Isolated from Stem of Syzygium aqueum and its Diuretic Activity
}

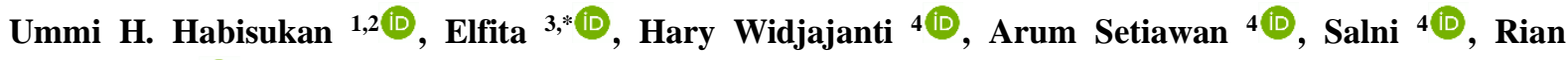 \\ Oktiansyah $^{2}$ (D)
}

1 Graduate School of Sciences, Faculty of Mathematics and Natural Sciences, University of Sriwijaya,. J1. Padang Selasa No. 524, Palembang 30139, South Sumatra, Indonesia; ummihirashabisukan@ radenfatah.ac.id (U.H.H.);

2 Universitas Islam Negeri Raden Fatah Palembang, South Sumatra, Indonesia; ummihirashabisukan@radenfatah.ac.id (U.H.H.); rianoktiansyah@ @radenfatah.ac.id (R.O.);

3 Department of Chemistry, Faculty of Mathematics and Natural Sciences, University of Sriwijaya, Jl. Palembang Prabumulih, Indralaya, South Sumatra, 30662 Indonesia; elfita.elfita.69@gmail.com (E.)

4 Department of Biology, Faculty of Mathematics and Natural Sciences, University of Sriwijaya, Jl. Palembang Prabumulih, Indralaya, South Sumatra, 30662 Indonesia; hary_widjajanti@unsri.ac.id (H.W.); arum.setiawan@unsri.ac.id (A.S.); salnibasir@unsri.ac.id (S.);

* Correspondence: elfita.elfita.69@gmail.com (E.);

Scopus Author ID 55532411800

Received: 20.09.2021; Revised: 25.10.2021; Accepted: 28.10.2021; Published: 21.11.2021

\begin{abstract}
Guava (Syzygium aqueum), a typical Indonesian crop plant, has diuretic properties. Plants used as diuretic medicines can also be valuable sources for endophytic fungi containing diuretic drugs. The aims of this study were to isolate and identify endophytic fungi from S. aqueum stems, to isolate their secondary metabolites, and to conduct in vivo tests of the diuretic activity of an endophytic fungus extract on white male rats of the Wistar strain. Endophytic fungi were isolated by a direct plating method, and fungal isolates were identified molecularly. A phenolic compound was isolated by chromatography, and the chemical structure was identified spectroscopically. Doses of 100, 200, and $300 \mathrm{mg} / \mathrm{kg} \mathrm{BW}$ were administered to white male rats divided into six groups (normal control, negative control, positive control, and the three treatment groups). Diuretic tests included urine volume; sodium, chloride, and calcium electrolyte levels; and pH. Phylogenetic analysis identified the endophytic fungal isolate as Trichoderma ghanense (isolation code SA1). The secondary metabolite isolated from the $T$. ghanense extract was a phenolic compound. Diuretic tests using the endophytic fungus extract showed the highest urine volume with a dose of $300 \mathrm{mg} / \mathrm{kg} \mathrm{BW}$. The diuretic test results showed an increase in urine volume and levels of sodium, potassium, and chloride ions in the urine. The extract of T. ghanense isolated from the stem of $S$. aqueum has the potential as initial therapy for hypertension because it contains phenolic secondary metabolites that show diuretic activity.
\end{abstract}

Keywords: diuretic; endophytic fungi; secondary metabolite; Syzygium aqueum.

(C) 2021 by the authors. This article is an open-access article distributed under the terms and conditions of the Creative Commons Attribution (CC BY) license (https://creativecommons.org/licenses/by/4.0/).

\section{Introduction}

Treating ailments such as hypertension, nephrotic syndrome, cirrhosis, and heart conditions includes diuretics to flush out excessive fluids within the body [1]. Diuretics cause an increase in the production and excretion of urine by the kidneys to promote the removal of toxins, excess water, and accumulated metabolic products, such as urea, from the body [2]. However, their use is sometimes accompanied by a loss of electrolytes, such as sodium, chloride, and potassium. Diuretics function to rid the body of excess fluid (edema) accumulated in tissues due to various disease states $[3,4]$. 
One plant with traditionally reported diuretic properties is guava (Syzygium aqueum), a typical crop plant from Indonesia. This plant has also been used in various parts of the world to treat various diseases, including hypertension, diabetes, diarrhea, asthma, inflammation, skin diseases, fever, digestive complaints, and high cholesterol [5], [6]. One study stated that most of the 87 secondary metabolites isolated from parts of the Syzygium aqueum plant were phenolics or phenolic derivatives [7]. People in South Sumatra, Indonesia, have used a decoction of the leaves and stems of $S$. aqueum as a diuretic medicine and to treat hypertension and diabetes [8].

The implantation of S. aqueum and other medicinal plants in Indonesia still faces many obstacles in terms of production, including the unprofessional implementation of medicinal plant implantation activities, the inability of farmers to maintain the quality and quality of medicinal plants, and the lack of attention from the medicinal plant industry regarding the results of scientific research in product development. One potential strategy for working around these obstacles is to use endophytic fungi, which are fast becoming important biotechnological tools $[9,10]$. Endophytic fungi are microscopic living organisms that live in plant tissues for a certain period by forming colonies without harming their hosts [11]. These endophytic fungi can produce metabolites similar to those produced by their host or different new compounds; therefore, this microbial group has huge biotechnological potential for new drug discovery [1214]. Compounds produced by endophytic fungi from plants are often used as antioxidants, antidiabetics, cancer, and diseases caused by oxidative damage [15-17]. Syzygium aqueum contains compounds such as flavonoids, phenolics, tannins, terpenoids which are often used as antioxidants, anticancer, antiviral, anti-inflammatory [7]. The endophytic fungi are also believed to contain the same compounds and activities. From two of Syzygium aqueum, an antioxidant compound identified as 4-hydroxy-3-(4-hydroxyphenyl)-5-oxotetrahydrofuran-2yl has been isolated [11]. The endophytic fungi associated with the plant Syzygium aqueum could represent ideal sources of diuretic drugs.

\section{Materials and Methods}

\subsection{Chemical and drug.}

Alcohol 70\%, distilled water, sodium hypochlorite $(\mathrm{NaOCl})$, chloramphenicol (Chloromex ${ }^{\circledR}$ Actavis, Indonesia), Potato Dextrose Agar (PDA) Merck, Potato Dextrose Broth (PDB) Merck, Silica gel 60 (70-230 mesh) Merck, thin layer chromatography (TLC), Silica gel 60 F254 Merck (Art.5554), methanol, aseton, ethyl acetate, chloroform, n-hexane (Merck), furosemide (Lasix ${ }^{\circledR}$, Aventis Indonesia Pharma, Indonesia), tween $801 \%$.

\subsection{Plant material.}

The fresh stem of Syzygium aqueum was collected from Martapura, South Sumatra, Indonesia $\left(4.17248^{\circ} \mathrm{S}, 104.20472^{\circ} \mathrm{E}\right)$. Plant identification was carried out at the Indonesian Institute of Sciences, Plant Conservation Center, Purwodadi Botanical Gardens, Certificate of Identification No.: B-301/III /KS.01.03/1/2021.

\subsection{Isolation and identification of endophytic fungi.}

Syzygium aqueum stems were washed under running water to remove dirt. The stem surface was sterilized by immersion in $70 \%$ ethanol for $2 \mathrm{~min}$, followed by $4 \% \mathrm{NaOCl}$ for 1 
min and two rinses in sterile distilled water. The plant stems were dried on sterile filter paper and then cut aseptically into $1 \times 1 \mathrm{~cm}$ pieces, which were then planted directly in a Petri dish containing PDA plus chloramphenicol and incubated at $25{ }^{\circ} \mathrm{C}$ for $2-5$ days. The tip of the hyphae growing out of each segment was transferred to a Petri dish containing new PDA and then re-incubated for approximately 14 days. Pure cultures were obtained after several subcultures and grown on PDA plates without antibiotics [18].

Identification of endophytic fungi was carried out based on partial genetic analysis on the Internal Transcribed Spacer (ITS) of fungal ribosomal DNA. PCR amplification using ITS Primer 4:5'- TCC TCC GCT TAT TGA TAT GC - 3' and ITS Primer 5:5' -GGA AGT AAA AGT CGT AAC AAG G-3' . The purified polymerase chain reaction (PCR) product was then precipitated, followed by cyclic sequencing. The result was purified again by the ethanol purification method. Sequencing was performed using an automated DNA sequencer. Sequence data were trimmed and assembled, followed by alignment BLAST using genomic data at the NCBI (National Center for Biotechnology Information) for analysis of homology/similarity and creation of a phylogenetic tree [19].

\subsection{Cultivation and extraction.}

Endophytic fungal suspensions were inoculated in $300 \mathrm{~mL}$ potato dextrose broth (PDB), placed in $1 \mathrm{~L}$ bottles ( $9 \mathrm{~L}$ in 30 bottles), and incubated for 4 weeks at room temperature under static conditions. The endophytic fungal mycelium in each bottle was removed using tweezers, and the medium was filtered through filter paper. The filtrate was extracted with ethyl acetate at a 1:1 ratio. The filtrate and solvent were separated in a separating funnel to obtain an ethyl acetate extract, which was concentrated using a rotary evaporator [11].

\subsection{Isolation and identification of secondary metabolites.}

The endophytic fungal extracts from Syzygium aqueum were separated by column chromatography (stationary phase: silica gel) and eluted with a graded eluent (n-hexane: ethyl acetate: methanol). The eluate droplets were collected in a $10 \mathrm{~mL}$ bottle and analyzed by TLC to group the bottles into subfractions. Subfractions identified as having secondary metabolites were further purified by column chromatography until pure compounds were obtained. The structures were identified by $1 \mathrm{D}$ and 2D NMR [20].

\subsection{Design of the test animal experiments animals.}

The test animals were male Wistar rats (weight 150-250 g) obtained from Abduh Tikus Palembang, South Sumatra, Indonesia. All animals were housed at $25 \pm 2{ }^{\circ} \mathrm{C}$ and a $12 \mathrm{~h}$ light/dark cycle in polypropylene cages with clean rice husks as bedding. The test animals were acclimatized in the laboratory for 7 days. All animals were provided standard rodent food and drinking water ad libitum. The animal experiment protocol was approved by the Research Ethics Committee of Ahmad Dahlan University, Yogyakarta, Indonesia, with approval number: 022107033 dated August 27, 2021.

Table 1. Test animal treatment group.

\begin{tabular}{c|c|c} 
No & Category & Treatment \\
\hline 1 & Normal control & Aquadest \\
\hline 2 & Negative control & Aquadest $+\mathrm{NaCl} 4,5 \%+$ tween 80 suspension $1 \%$ \\
\hline 3 & Positive control & Aquadest $+\mathrm{NaCl} 4,5 \%+$ furosemide suspension \\
\hline
\end{tabular}




\begin{tabular}{c|c|c}
\hline No & Category & Treatment \\
\hline 4 & Treatment 1 & Aquadest $+\mathrm{NaCl} 4,5 \%+$ mushroom extract suspension dose $100 \mathrm{mg} / \mathrm{kgBB}$ \\
\hline 5 & Treatment 2 & Aquadest $+\mathrm{NaCl} 4,5 \%+$ mushroom extract suspension dose $200 \mathrm{mg} / \mathrm{kgBB}$ \\
\hline 6 & Treatment 3 & Aquadest $+\mathrm{NaCl} 4,5 \%+$ mushroom extract suspension dose $300 \mathrm{mg} / \mathrm{kgBB}$
\end{tabular}

\subsection{Preparation for assays.}

Suspensions of endophytic fungal extract at doses of $100 \mathrm{mg} / \mathrm{kg} \mathrm{BW}, 200 \mathrm{mg} / \mathrm{kg} \mathrm{BW}$, and $300 \mathrm{mg} / \mathrm{kg} \mathrm{BW}$ were prepared by grinding the endophytic fungal extract from Syzygium aqueum in a mortar according to the dose calculation $(1.5 \mathrm{~g}$ in $50 \mathrm{~mL}$ for the highest dose of $300 \mathrm{mg} / \mathrm{kg} \mathrm{BW}$ ), then dissolving in phosphate-buffered saline containing tween $801 \%$. The next dose was prepared by diluting the mother liquor (the highest dose).

\subsection{Test of diuretic effect.}

The test animal was divided into 6 treatment groups, consisting of 4 rats (Table 1). Before testing, the animals fasted for $18 \mathrm{~h}$. Samples were given using a gastric probe. After treatment, the test animals were put into metabolic cages to collect their urine. Urine volume was measured after administration of the extract at 1,2,3,4,5, and $6 \mathrm{~h}$, and cumulative urine volume was determined after $24 \mathrm{~h}$. Drinking water at 1 to $6 \mathrm{~h}$ was controlled by giving $2.5 \mathrm{~mL}$ of $4.5 \mathrm{ml} \mathrm{NaCl}$ every $3 \mathrm{~h}$ orally to each test animal, except for the normal group, which was given $2.5 \mathrm{~mL}$ distilled water. During the treatment, the test animals were not fed. The percentage potency of the diuretics was determined using the following equation [21]:

$\%$ Diuretic Potency $=$ extract treatment volume - negative treatment volume $\times 100 \%$

Positive treatment volume - negative treatment volume

Urinary $\mathrm{Na}^{+}, \mathrm{K}^{+}$, and $\mathrm{Cl}^{-}$levels were measured by atomic absorption spectroscopy (AAS) at wavelengths of $766.5 \mathrm{~nm}$ and $589.0 \mathrm{~nm}$ [22]. The $\mathrm{pH}$ was determined with a $\mathrm{pH}$ meter. The urine was fresh or preserved so that ammonia was not produced by urea breakdown. Data Analysis

The results of the study were expressed as mean \pm standard error of the mean (SEM). The data were statistically analyzed by one-way analysis of variance (ANOVA) followed by a Tukey post hoc multiple comparison test. P-values less than 0.05 were considered statistically significant.

\section{Results and Discussion}

\subsection{Isolation and identification of endophytic fungi.}

The endophytic fungi isolated from the stems of Syzygium aqueum were given the isolation code SA1 (Figure 1). The results of the molecular identification of the $649 \mathrm{bp}$ sequence of the SA1 endophytic fungus were as follows: GATCCTTCCGTAGGTGAACCTGCGGAGGGATCATTACCGAGTTTACAACTCCCAA ACCCCAATGTGAACGTTACCAATCTGTTGCCTCGGCGGGATTCTCTGCCCCGGGC GCGTCGCAGCCCCGGATCCCATGGCGCCCGCCGGAGGACCAACCAAACTCTTTTT TCTCTCCGTCGCGGCTTCCGTCGCGGCTCTGTTTTAACCTTTGCTCTGAGCCTTTCT CGGCGACCCTAGCGGGCGTCTCGAAAATGAATCAAAACTTTCAACAACGGATCT CTTGGTTCTGGCATCGATGAAGAACGCAGCGAAATGCGATAAGTAATGTGAATT 
GCAGAATTCAGTGAATCATCGAATCTTTGAACGCACATTGCGCCCGCCAGTATTC TGGCGGGCATGCCTGTCCGAGCGTCATTTCAACCCTCGAACCCCTCCGGGGGTCC GGCGTTGGGGATCGGCACGCCCTCACACGGGTGCCGGCCCCGAAATCCAGTGGC GGTCTCGCCGCAGCCTCTCCTGCGCAGTAGTTTGCACACTCGCACCGGGAGCGCG GCGCGGCCACAGCCGTAAAACACCCCAAACTTCTGAAATGTTGACCTCGGATCA GGTAGGAATACCCGCTGAACTTAAGCATATCAATAAGCCGGAGGAA.

The SA1 strain was given the accession number SUB10223461 SA1 MZ855361. The SA1 endophytic fungus had the highest homology with Trichoderma ghanense MF078652. The phylogenetic analysis followed the described method shown in Figure 2.

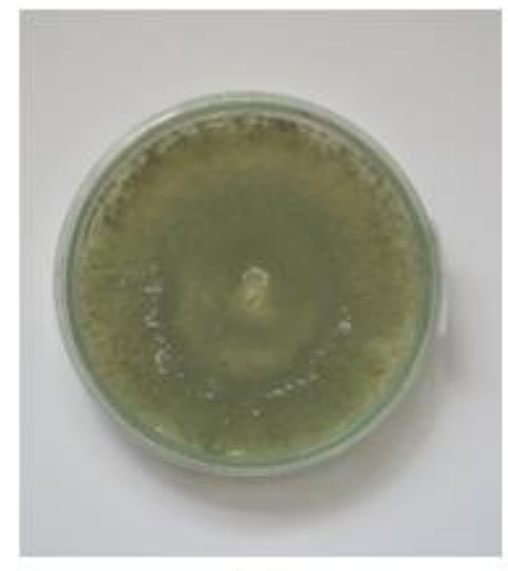

(a)

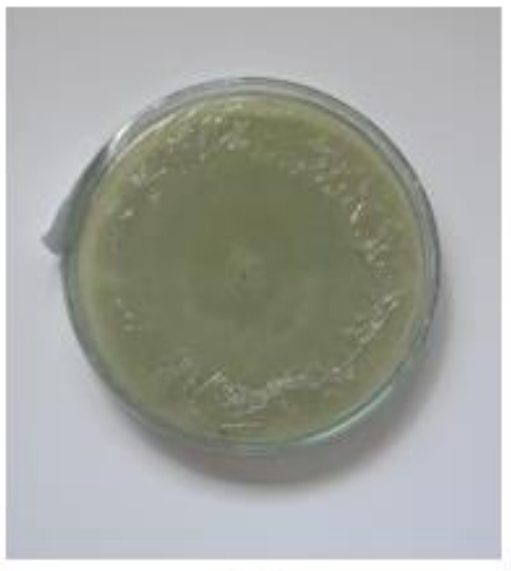

(b)

Figure 1. Endophytic fungi isolation results from Syzygium aqueum stem. (a) SA1 isolate in front; (b) SA1 isolate in back.

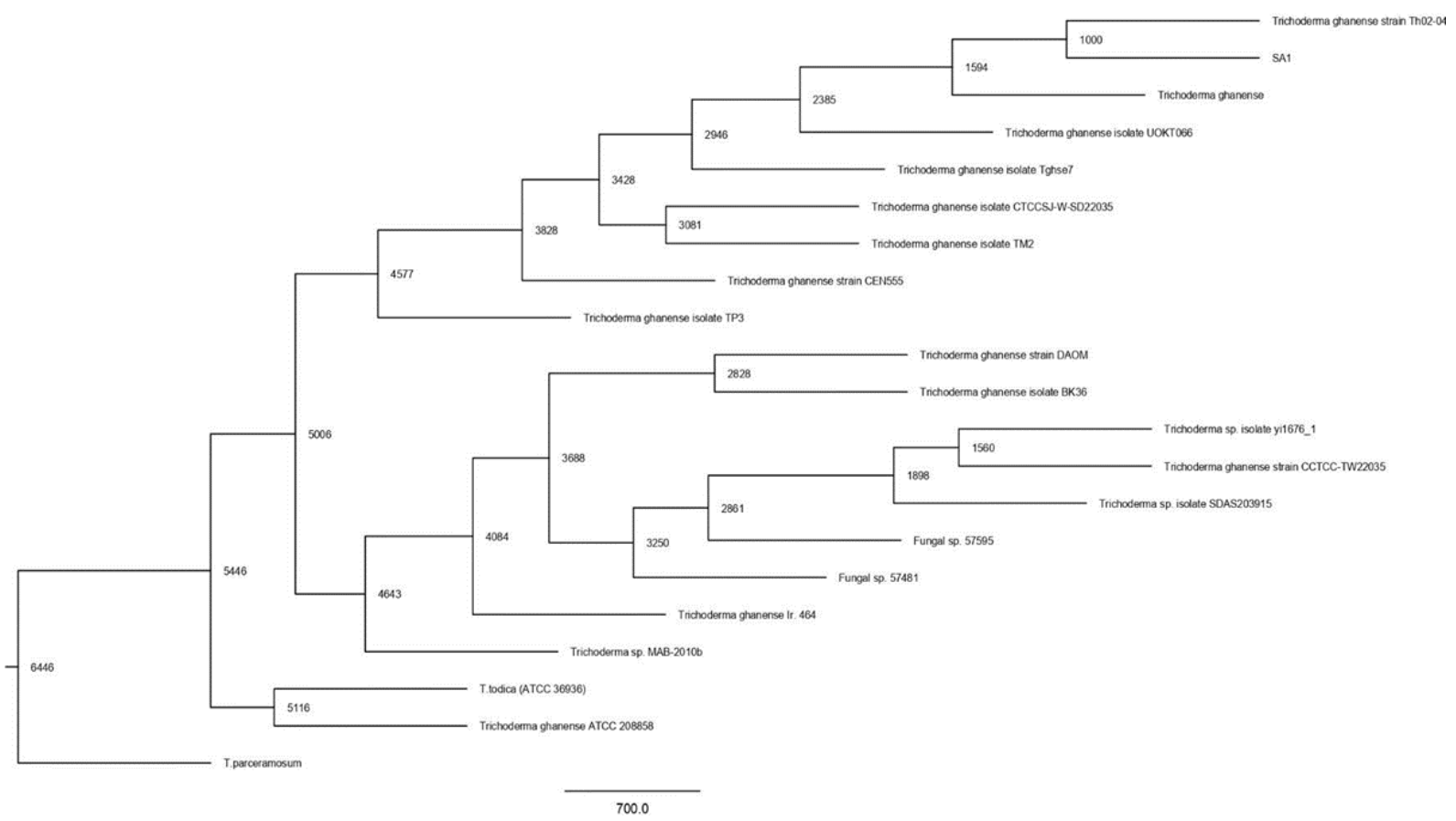

Figure 2. Phylogenetic tree from endophytic fungi SA1.

3.2. Isolation of secondary metabolic compounds from the endophytic fungus.

The separation of $2 \mathrm{~g}$ of the concentrated SA1 endophytic fungal extract (silica gel: 70 230 mesh; $20 \mathrm{~g})$ generated subfraction SA1.7 (128.7 $\mathrm{mg})$, giving a purple stain on TLC analysis. The compound was purified using column chromatography (silica gel 70-230 mesh; 
$10 \mathrm{~g})$ and eluted with hexane: ethyl acetate (7:3-4:6) to yield four subfractions (SA1.7.1SA1.7.4). The SA1.7.3 fraction ( $55 \mathrm{mg}$ ) was further purified by column chromatography until compound 1 (43 mg) was obtained.

The ${ }^{1} \mathrm{H}-\mathrm{NMR}$ spectrum of compound 1 (Figure 3 (A)) revealed the presence of seven proton signals; four for the sp3 proton, including a methyl signal at $\delta_{\mathrm{H}} 1.25 \mathrm{ppm}(3 \mathrm{H}, \mathrm{d}, \mathrm{J}=1.5$ $\mathrm{Hz}$ ) and a methine proton signal at $\delta_{\mathrm{H}} 4.17 \mathrm{ppm}(1 \mathrm{H}, \mathrm{m})$, and three oxygenated methine signals at $\delta_{\mathrm{H}} 4.02(2 \mathrm{H}, \mathrm{m}), 5.34(1 \mathrm{H}, \mathrm{d}, \mathrm{J}=2.5 \mathrm{~Hz})$, and $5.79 \mathrm{ppm}(1 \mathrm{H}, \mathrm{s})$. The spectrum is in the aromatic chemical shift region, at $\delta_{\mathrm{H}} 7.58$ and $8.22 \mathrm{ppm}$. The spectrum of each signal shows a doublet with the same plot constant $\mathrm{J}=8.0 \mathrm{~Hz}$, indicating the integration of two protons. Therefore, compound 1 is a para-substituted aromatic compound, so it has two pairs of equivalent protons. Analysis of the ${ }^{1} \mathrm{H}-\mathrm{NMR}$ spectrum revealed compound 1 as a parasubstituted aromatic compound with 12 protons attached to a carbon atom. The solvent used in this measurement is $\mathrm{CDCl}_{3}$, so the protons bound to the heteroatoms do not appear in the spectrum.

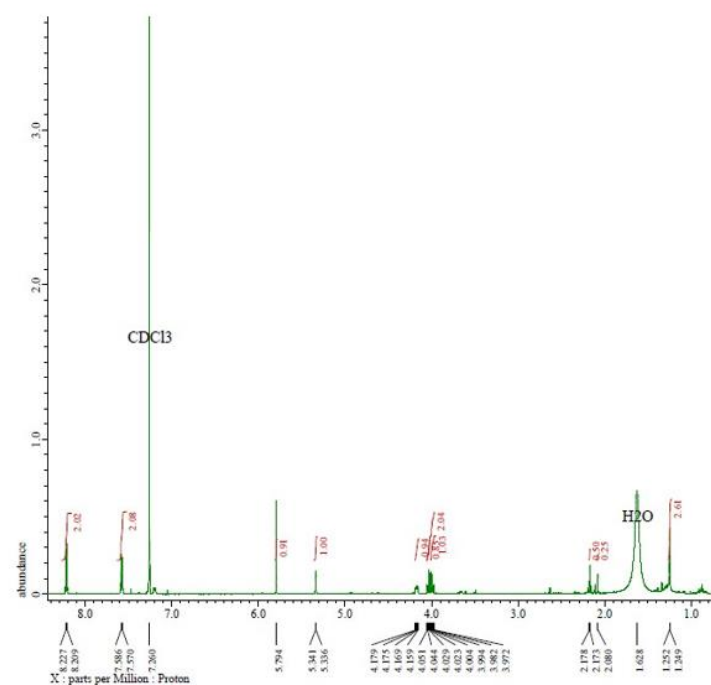

(a)

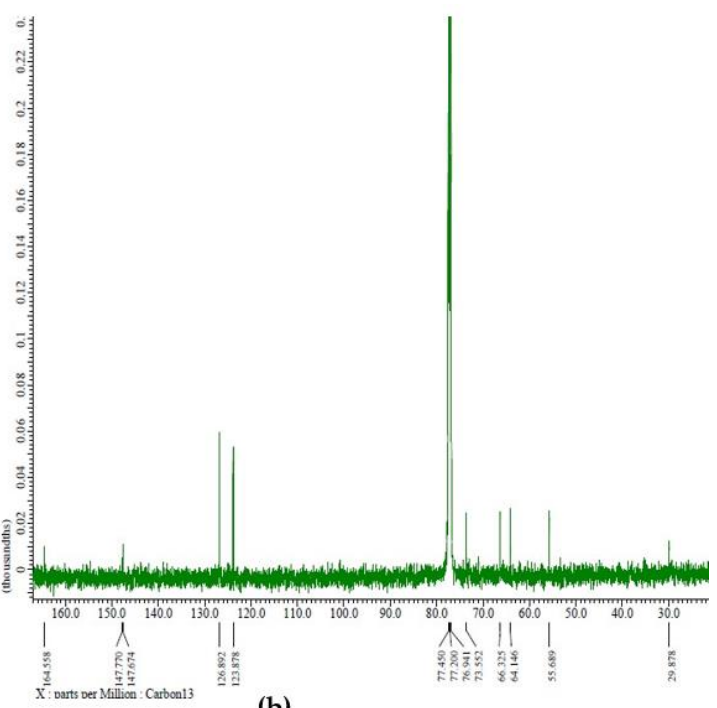

(b)

Figure 3. (a) ${ }^{1} \mathrm{H}-\mathrm{NMR}$ spectrum; (b) ${ }^{13} \mathrm{C}-\mathrm{NMR}$ of compound 1.

The ${ }^{13} \mathrm{C}$-NMR spectrum of compound 1 (Figure 3(B)) showed the presence of nine signals: five sp 3 carbon signals, including three signals in the oxygenated carbon area at $\delta_{\mathrm{C}}$ 64.1, 66.3, and $73.6 \mathrm{ppm}$. Four other signals appear in the aromatic region as two high-intensity signals, indicating that compound 1 has two pairs of equivalent aromatic carbons $\left(\delta_{\mathrm{C}} 126.8\right.$ and $123.8 \mathrm{ppm}$ ), and as two low-intensity signals, indicating the presence of quaternary carbon, one of which is an oxyaryl carbon in the low field $\left(\delta_{\mathrm{C}} 164.6 \mathrm{ppm}\right)$. Analyses of the proton and carbon NMR spectra were confirmed by the data on the heteronuclear multiple quantum coherence (HMQC) spectrum shown in Figure 4 and Table 2, namely the ${ }^{1} \mathrm{H}-{ }^{13} \mathrm{C}$ correlation through one bond. The HMQC spectrum showed seven correlations consisting of two correlations on the aromatic ring, three correlations on oxygenated ${ }^{1} \mathrm{H}-{ }^{13} \mathrm{C}$, one proton correlation of methine, and one correlation of proton methyl.

The heteronuclear multiple bond correlation (HMBC) spectrum (Figure 5) shows the ${ }^{1} \mathrm{H}$ ${ }^{13} \mathrm{C}$ correlation through two or three bonds. The aromatic proton signal at $\delta_{\mathrm{H}} 8.22 \mathrm{ppm}$ indicates the existence of two correlations, one to carbon $\delta_{\mathrm{C}} 123.9$, which is the carbon equivalent, and the other to $\delta_{\mathrm{C}} 147.7$, which is the aromatic quaternary carbon. Another aromatic proton at $\delta_{\mathrm{H}}$ $7.58 \mathrm{ppm}$ has three correlations, each with carbon at $\delta_{\mathrm{C}} 126.9 \mathrm{ppm}$, which is the carbon 
equivalent, $\delta_{\mathrm{C}} 147.7$ and $\delta_{\mathrm{C}} 73.6 \mathrm{ppm}$, which is oxygenated carbon directly bonded to the aromatic ring. Oxygenated methine protons at $\delta_{\mathrm{H}} 5.34 \mathrm{ppm}$ also have three correlations to carbons at $\delta_{\mathrm{C}} 66.3,147.7$, and $126.9 \mathrm{ppm}$.
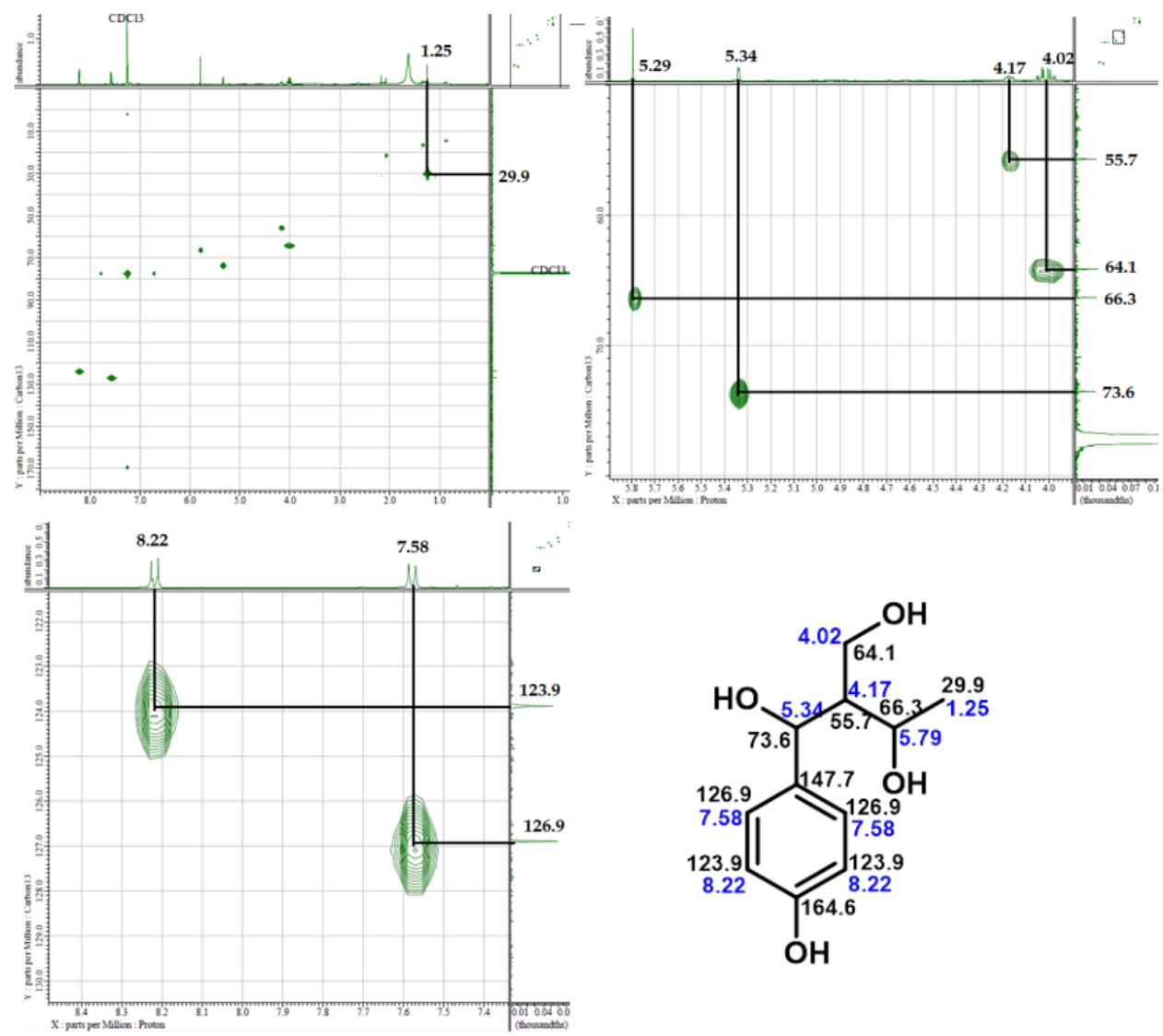

Figure 4. The HMQC spectrum and placement of the ${ }^{1} \mathrm{H}$ and ${ }^{13} \mathrm{C}$ shift in compound 1.

Table 2. The NMR data of Compound 1.

\begin{tabular}{|c|c|c|c|c|}
\hline No. C & $\delta \mathbf{C ~ p p m}$ & $\delta_{H}$ ppm $(\Sigma H$. multiplicity. $J(\mathbf{H z}))$ & HМBC & COSY \\
\hline 1 & 73.6 & $5.34(1 \mathrm{H}, \mathrm{d}, \mathrm{J}=2.5 \mathrm{~Hz})$ & $66.3 ; 147.7 ; 126.9$ & 4.17 \\
\hline 2 & 55.7 & $4.17(1 \mathrm{H}, \mathrm{m})$ & & 5.34 \\
\hline 3 & 66.3 & $5.79(1 \mathrm{H}, \mathrm{s})$ & & \\
\hline 4 & 29.9 & $1.25(3 \mathrm{H}, \mathrm{d}, \mathrm{J}=1.5 \mathrm{~Hz})$ & 55.7 & \\
\hline 5 & 64.1 & $4.02(2 \mathrm{H}, \mathrm{m})$ & 73.6 & \\
\hline$\overline{1}$ & 147.7 & & & \\
\hline 2 ' & 126.9 & $7.58(1 \mathrm{H}, \mathrm{d}, \mathrm{J}=8.0 \mathrm{~Hz})$ & $126.9 ; 147.7 ; 73.6$ & 8.22 \\
\hline 3 , & 123.9 & $8.22(1 \mathrm{H}, \mathrm{d}, \mathrm{J}=8.0 \mathrm{~Hz})$ & $123.9 ; 147.7$ & 7.58 \\
\hline 4 & 164.6 & & & \\
\hline 5, & 123.9 & $8.22(1 \mathrm{H}, \mathrm{d}, \mathrm{J}=8.0 \mathrm{~Hz})$ & $123.9 ; 147.7$ & 7.58 \\
\hline 6 ' & 126.9 & $7.58(1 \mathrm{H}, \mathrm{d}, \mathrm{J}=8.0 \mathrm{~Hz})$ & $126.9 ; 147.7 ; 73.6$ & 8.22 \\
\hline
\end{tabular}

The correlation indicates that the oxygenated methinegroup at $\delta_{\mathrm{H}} 5.34 \mathrm{ppm}$ is directly bound to the aromatic ring and is para-substituted with a hydroxyl group. The proton hydroxyl signal does not appear on the spectrum because the purecompound is measured with $\mathrm{CDCl}_{3}$ as the solvent. The 1D and 2D NMR spectral data for compound 1 are shown in Table 2.

The COSY spectrum in Figure 6 shows the ${ }^{1} \mathrm{H}-{ }^{1} \mathrm{H}$ correlation through three bonds. Two types of correlation are evident: the correlation of the aromatic proton at $\delta_{\mathrm{H}} 8.22 \mathrm{ppm}$ with the aromatic proton at $\delta_{\mathrm{H}} 7.57 \mathrm{ppm}$ and the proton sp3 correlation of the substituent group, namely the oxygenated proton of methine at $\delta_{\mathrm{H}} 5.34 \mathrm{ppm}$ with the proton of methine at $4.17 \mathrm{ppm}$. 


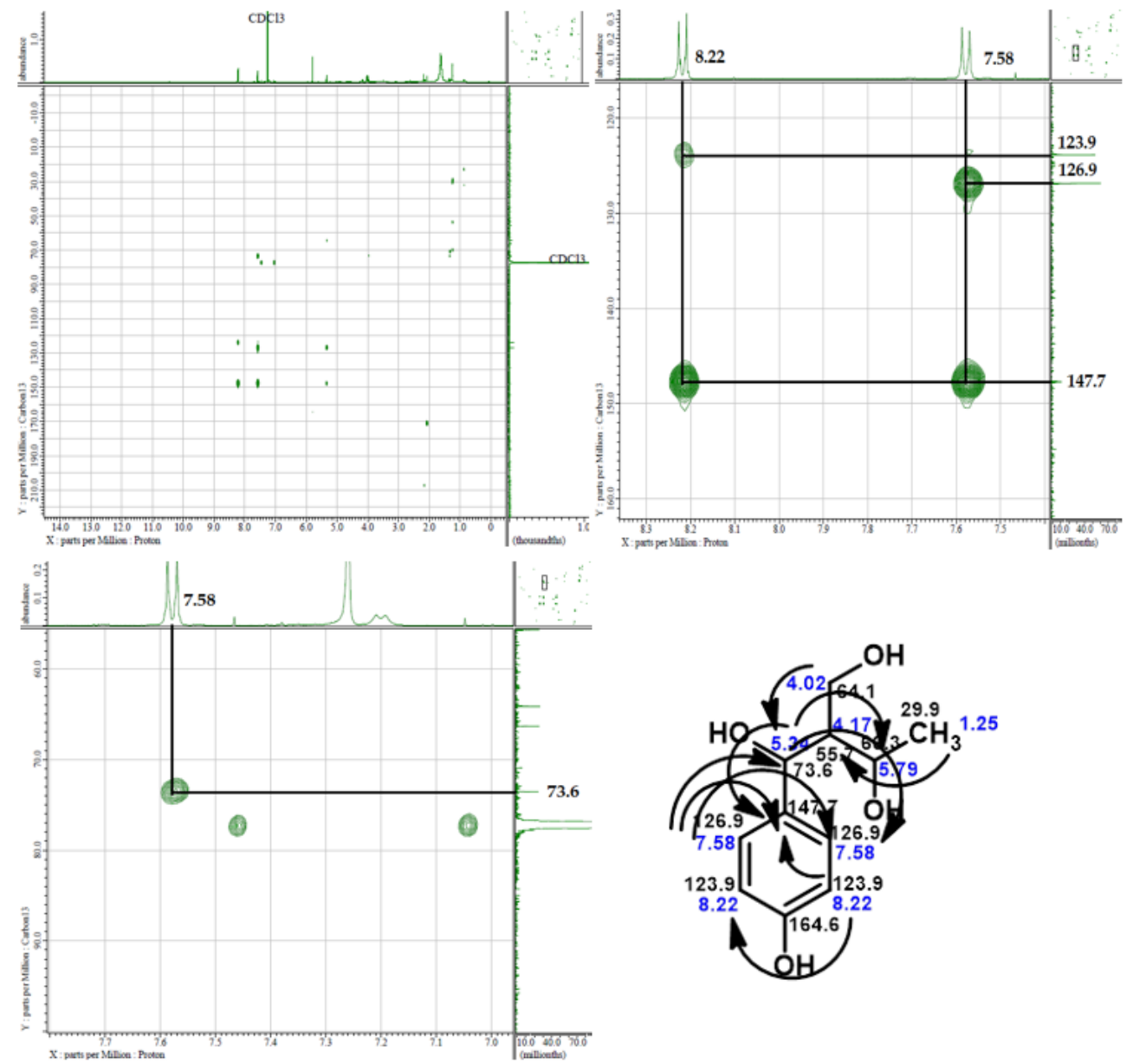

Figure 5. The HMBC spectrum and the correlation ${ }^{1} \mathrm{H}-{ }^{13} \mathrm{C}$ through two or three bonds in compound 1.

This indicates that the two aromatic equivalent protons are in the ortho position. This strengthens the proposed structure of compound 1 as a benzene ring directly bonded to the oxygenated methine carbon at the para position with a hydroxyl group.

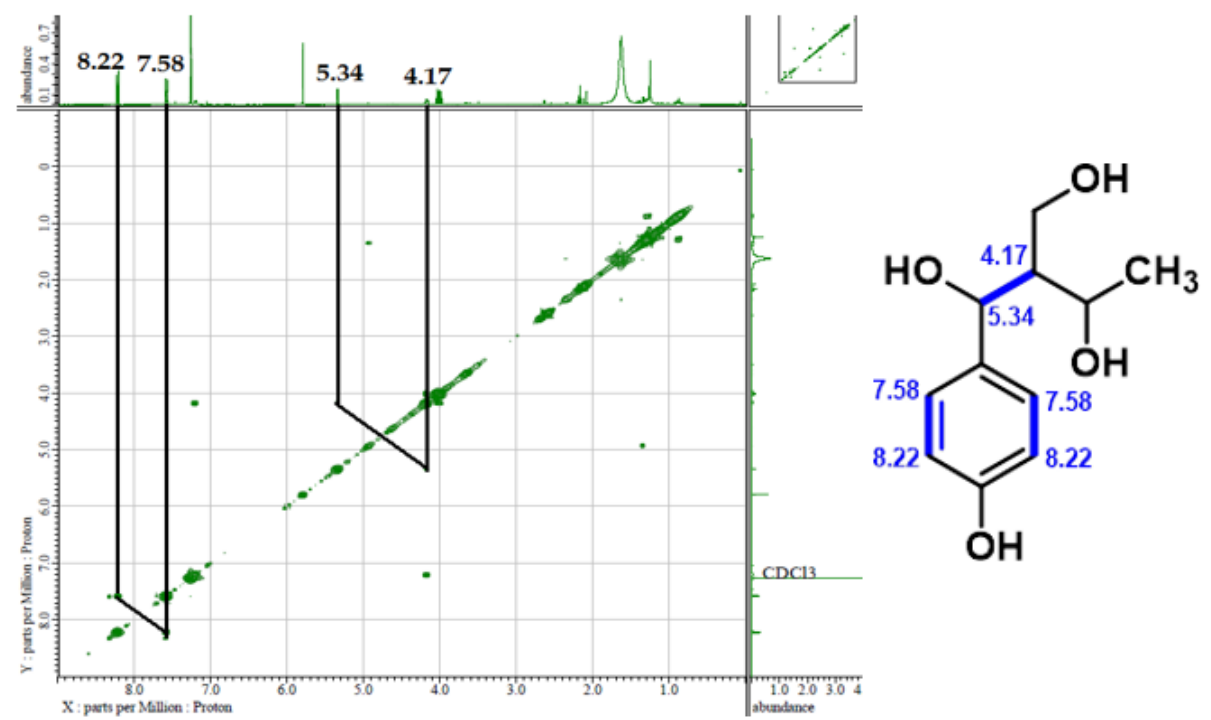

Figure 6. COSY spectrum and the correlation ${ }^{1} \mathrm{H}-{ }^{1} \mathrm{H}$ in compound 1.

The spectrum analyses by ${ }^{1} \mathrm{H}-\mathrm{NMR},{ }^{13} \mathrm{C}-\mathrm{NMR}$, HMQC, HMBC, and COSY can explain that compound 1 has a benzene ring that is substituted at the para position with a hydroxyl group and an oxygenated methine group that is part of the substituent group, namely 2- (hydroxymethyl)butane-1,3-diol. The proton at H 5.78 ppm appears as a singlet, probably https://biointerfaceresearch.com/ 
because the neighboring proton, which is three bonds apart, is in the farthest geometric position; therefore, cleavage and/or other factors, such as inappropriate resolution, do not occur. Thus, the proposed chemical structure of compound 1 is 2-(hydroxymethyl)-1-(-4hydroxyphenyl)butane-1,3-diol, as shown in Figure 7.

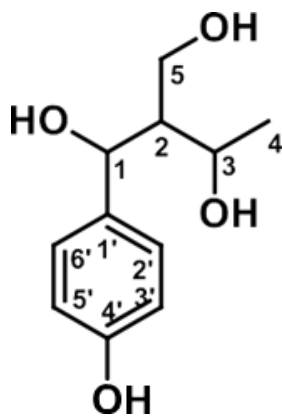

Figure 7. Structure compound of 3-(hydroxymethyl)-1-(-4-hydroxyphenyl)butane-1,3-diol.

\subsection{Test of diuretic effect.}

The total urine volume produced was larger in the treatment group than in the normal and negative groups. This indicates a diuretic effect of the extract on urine excretion. The highest urine volume was produced by the positive control group; the data for the treatment group can be seen in Table 3 .

Table 3. Total Urine Volume and Diuretic Potency.

\begin{tabular}{|c|c|c|c|c|c|c|c|c|}
\hline Group & I hour & 2 hour & 3 hour & 4 hour & 5 hour & 6 hour & 24 hour & $\begin{array}{l}\% \text { Diuretic } \\
\text { Potency }\end{array}$ \\
\hline Normal & $1,42 \pm 0,572$ & $2,42 \pm 0,453$ & $2,85 \pm 0,433$ & $3,30 \pm 0,248$ & $3,42 \pm 0,319$ & $3,57 \pm 0,278^{\mathrm{a}}$ & $6,37 \pm 0,327$ & 0 \\
\hline Negative & $1,17 \pm 0,411$ & $2,02 \pm 0,652$ & $2,32 \pm 0,850$ & $3,77 \pm 1,048$ & $4,37 \pm 0,851$ & $4,57 \pm 0,797^{\mathrm{a}}$ & $7,50 \pm 0,659$ & 0 \\
\hline Treatment 1 & $0,62 \pm 0,252$ & $1,52 \pm 0,564$ & $2,20 \pm 0,696$ & $3,87 \pm 1,295$ & $4,75 \pm 1,420$ & $5,17 \pm 1,546^{\mathrm{a}}$ & $8,27 \pm 1,981$ & 20 \\
\hline Treatment 2 & $0,37 \pm 0,217$ & $1,20 \pm 0,535$ & $1,75 \pm 0,590$ & $3,90 \pm 0,994$ & $4,77 \pm 1,220$ & $5,67 \pm 0,900^{\mathrm{b}}$ & $8,67 \pm 1,697$ & 21,27 \\
\hline Treatment 3 & $1,45 \pm 0,132$ & $2,67 \pm 0,406$ & $2,92 \pm 0,314$ & $6,70 \pm 0,817$ & $7,05 \pm 0,790$ & $7,70 \pm 0,994^{\mathrm{c}}$ & $11,00 \pm 1,511$ & 93,95 \\
\hline Positive & $1,25 \pm 0,221$ & $2,65 \pm 0,457$ & $4,35 \pm 0,800$ & $7,32 \pm 1,145$ & $8,07 \pm 1,416$ & $8,42 \pm 1,353^{\mathrm{d}}$ & $11,22 \pm 1,915$ & 100 \\
\hline
\end{tabular}

Treatment with the extract increased urine volume or diuresis as a ratio between the dose and diuretic potency $(\mathrm{R}=0.78)$. The increase in urine volume occurs due to the inhibition of water reabsorption in the kidneys [23]. The increase in urine volume in the treatment group compared to the negative and normal groups occurred at 4-6 hours, due to the working time of furosemide at 4-6 hours, while the treatment groups 1-3 also showed a similar response, indicating that the working time of the extract was the same as the working time of furosemide [24] The treatment dose that had the highest diuretic potential was treatment 3, with a diuretic potency of $93.95 \%(\mathrm{P}<0.003)$, whereas it was considered $0 \%(\mathrm{P}<0.00)$ for the control and negative groups because those were the baseline references for the diuretic effect of the extract.

Previous studies have revealed that phenolics can inhibit the carbonic enzyme anhydrase in the renal tubules. Phenolics increase diuresis because they inhibit the angiotensinconverting enzyme (ACE) [25,26]. Cumulatively, the results for the urine volumes were greater for each treatment group than for the negative and normal control groups. The results of oneway ANOVA for the total urine volume $(\mathrm{p}=0.003)$ indicate a significant difference between the test groups. The homogeneity test resulted in a Levene statistic of 2.257 with $p=0.523$, showing that the test data have the same variance or are homogeneous. 
The $\mathrm{pH}$ value of urine (Table 4) is determined by acid-base regulation in the kidneys. If a certain amount of $\mathrm{HCO}^{3-}$ is continuously filtered into the renal tubules and excreted in the urine, the urine will be alkaline, as was observed in this study, where the $\mathrm{pH}$ value was $\mathrm{pH}$ 910 [27]. By contrast, if $\mathrm{H}^{+}$ions were continuously filtered into the kidney tubules and excreted into the urine, the urine would be acidic [28]. The kidneys have several mechanisms for regulating the concentration of $\mathrm{H}^{+}$ions, including secretion of $\mathrm{H}^{+}$ions into the tubules, reabsorption of $\mathrm{HCO}^{-}$ions, and production of new $\mathrm{HCO}^{-}$ions. All these mechanisms reduce and neutralize excess $\mathrm{H}^{+}$ions in the body $[29,30]$.

Table 4. $\mathrm{pH}$ measurement.

\begin{tabular}{l|l} 
Treatment category & Urine $\mathbf{~ H}$ \\
\hline Normal & $10,00 \pm 0,000$ \\
\hline Negative & $10,00 \pm 0,000$ \\
\hline Treatment 1 & $09,50 \pm 0,288$ \\
\hline Treatment 2 & $09,00 \pm 0,000$ \\
\hline Treatment 3 & $09,50 \pm 0,288$ \\
\hline Positive & $10,00 \pm 0,000$
\end{tabular}

Each value represents the mean \pm S.E.M (Standard Error of Mean); $\mathrm{n}=4$. Positive: furosemide $20 \mathrm{mg} / \mathrm{kgBW}$, Treatment 1 (100 mg/kgBW), Treatment 2 (200mg/kgBW), Treatment 3 (300 mg/kgBW)

The increase in diuresis caused by the endophytic fungal from $S$. aqueum was also evident in the excretion of electrolytes. The extract significantly increased the excretion of urinary electrolytes, such as $\mathrm{Na}^{+}, \mathrm{K}^{+}$, and $\mathrm{Cl}^{-}$(Table 5). This increase in electrolyte excretion is thought to be due to the endophytic fungi extract acting through a loop diuretic mechanism, thereby increasing the urine flow rate and in turn causing a decrease in the absorption of $\mathrm{Na}^{+}$, $\mathrm{K}^{+}$, and $\mathrm{Cl}^{-}$in the loop of Henle in the kidney [31,32]. This will increase the amount of water and salt excreted in the urine [33]. However, in the present study, the amount of $\mathrm{K}^{+}$excreted was not as large as the amounts of $\mathrm{Na}^{+}$and $\mathrm{Cl}^{-}$. This condition results from the antioxidant activity of the endophytic fungal extract, which reduces the side effects of loop diuretics so that the body can still absorb $\mathrm{K}^{+}[34,35]$. The saluretic activity of the three test groups was above 100 percent, compared to the positive control using furosemide. These results indicate that the extract has saluretic potential.

Table 5. Measurement of $\mathrm{Na}^{+}, \mathrm{K}^{+}$, and $\mathrm{Cl}^{-}$levels.

\begin{tabular}{|c|c|c|c|c|c|c|}
\hline $\begin{array}{l}\text { Treatment } \\
\text { Category }\end{array}$ & $\begin{array}{c}\mathrm{Na}^{+} \text {level } \\
(\mathrm{ppm})\end{array}$ & $\begin{array}{c}\mathbf{K}^{+} \text {level } \\
(\mathbf{p p m})\end{array}$ & $\begin{array}{l}\mathrm{Cl}^{-} \text {level } \\
\text { (ppm) }\end{array}$ & $\begin{array}{c}\text { Saturetic level } \\
\text { of } \mathrm{Na}(\%)\end{array}$ & $\begin{array}{c}\text { Saturetic level } \\
\text { of Cl }(\%)\end{array}$ & $\begin{array}{c}\text { Saturetic level } \\
\text { of } K(\%)\end{array}$ \\
\hline Normal & $200 \pm 1,154$ & $141,5 \pm 3,175$ & $141,5 \pm 3,175$ & 0 & 0 & 0 \\
\hline Negative & $247,5 \pm 8,948$ & $330 \pm 16,743$ & $386 \pm 73,323$ & 0 & 0 & 0 \\
\hline Treatment 1 & $363 \pm 16,454$ & $360,5 \pm 47,342$ & $360,5 \pm 47,342$ & 417,9 & 161,6 & 86,9 \\
\hline Treatment 2 & $272,5 \pm 7,794$ & $338 \pm 31,754$ & $338 \pm 31,754$ & 184,6 & 145 & 77,97 \\
\hline Treatment 3 & $363 \pm 15,011$ & $360,5 \pm 4,330$ & $360,5 \pm 4,330$ & 417,9 & 161,2 & 86,9 \\
\hline Positive & $239 \pm 3,464$ & $393,5 \pm 14,145$ & $277 \pm 81,406$ & 100 & 100 & 100 \\
\hline
\end{tabular}

Each value represents the mean \pm S.E.M (Standard Error of Mean); $\mathrm{n}=4$. Positive: furosemide $20 \mathrm{mg} / \mathrm{kgBW}$, Treatment 1 (100 mg/kgBW), Treatment $2(200 \mathrm{mg} / \mathrm{kgBW})$, Treatment $3(300 \mathrm{mg} / \mathrm{kgBW})$

\section{Conclusions}

The endophytic fungi extract from Syzygium aqueum contains a phenolic compound 2(hydroxymethyl)-1-(-4-hydroxyphenyl) butane-1,3-diol that has diuretic activity and increases the volume of excreted urine and its ion concentration. 


\section{Funding}

The research/publication of this article was funded by the DIPA of the Public Service Agency of Universitas Sriwijaya 2021. SP DIPA -023.17.2.677515/2021, on November 23, 2020. In accordance with the Rector's Decree Number: 0014/ UN9/ SK.LP2M.PT/2021, on May 25, 2021.

\section{Acknowledgments}

The authors wish to respect the facility's support of the Organic Chemistry and Microbiology Laboratory, Faculty of Mathematics and Natural Sciences, University of Sriwijaya also Palembang Health Laboratory Center, Ministry of Health of the Republic of Indonesia.

\section{Conflicts of Interest}

The authors declare no conflict of interest.

\section{References}

1. Jayanthi, M.K.; Aswathi, K.; Krishna, K.L.; Ramu, R. Evaluation of antioxidant and diuretic activities of Clitoria ternatea leaf extracts in Wistar albino rats. J Appl Pharm Sci 2021, 11, 152-157, http://dx.doi.org/10.7324/JAPS.2021.110118.

2. Trujillo, H.; Fontán, F.C.; Caro, J.; Morales, E.; Praga, M. The forgotten antiproteinuric properties of diuretics. Am J Nephrol 2021, 2021, 435-449, http://dx.doi.org/10.1159/000517020.

3. Divya B.; Fakrudin, B.; Devappa, V. Expression profiling of resistance gene analogs from french bean (Phaseolus vulgaris l.) for the manifestation of rust (Uromyces phaseoli l.). Int J Curr Microbiol Appl Sci 2019, 8, 1760-1773, http://dx.doi.org/10.20546/ijcmas.2019.803.206.

4. Shah, N.; Madanieh, R.; Alkan, M.; Dogar, M.U.; Kosmas, C.E.; Vittorio, T.J. A perspective on diuretic resistance in chronic congestive heart failure. Ther Adv Cardiovasc Dis 2017, 11, 271-278, http://dx.doi.org/10.1177/1753944717718717.

5. Cock, I.E.; Cheesman, M. Chapter 23 - The Potential of Plants of the Genus Syzygium (Myrtaceae) for the Prevention and Treatment of Arthritic and Autoimmune Diseases. In: Bioactive food as dietary interventions for arthritis and related inflammatory diseases. 2nd ed.; Academic Press: Elsevier Inc., 2019; pp. 401-424, http://dx.doi.org/10.1016/B978-0-12-813820-5.00023-4.

6. Itam, A.; Wati, M.S.; Agustin, V.; Sabri, N.; Jumanah, R.A.; Efdi, M. Comparative study of phytochemical, antioxidant, and cytotoxic activities and phenolic content of Syzygium aqueum (burm. f. alston f.) extracts growing in west sumatera indonesia. Sci World J 2021, 2021, 1-9, https://doi.org/10.1155/2021/5537597.

7. Sobeh, M. Syzygium aqueum: a polyphenol- rich leaf extract exhibits antioxidant, hepatoprotective, painkilling and anti-inflammatory activities in animal models. Front Pharmacol 2018, 9, 1-14, http://dx.doi.org/10.3389/fphar.2018.00566.

8. Habisukan, U.H.; Elfita; Widjajanti, H.; Setiawan, A.; Kurniawati, A.R. Antioxidant and antimicrobial activity of endophytyc fungi isolated from Syzygium aqueum leaves. J Phys Conf Ser 2021, 1751, 1-8.

9. Park, C.H. In vitro antioxidant and antimicrobial properties of flower, leaf, and stem extracts of korean mint. Antioxidants 2019, 8, 1-12, http://dx.doi.org/10.3390/antiox8030075.

10. Wei, L.; Yang, M.; Huang, L.; Li, J.L. Antibacterial and antioxidant flavonoid derivatives from the fruits of Metaplexis japonica. Food Chem 2019, 289, 308-312, http://dx.doi.org/10.1016/j.foodchem.2019.03.070.

11. Habisukan, U.H.; Elfita; Widjajanti, H; Setiawan, A. Chemical characterization of secondary metabolite from the endophytic fungus trichordema reecei isolated from the twig of syzygium aqueum. Sci Technol Indones 2021, 6, 137-143, http://dx.doi.org/10.26554/sti.2021.6.3.137-143.

12. Cruz, J.S.; da Silva, C.A.; Hamerski, L. Natural products from endophytic fungi associated with rubiaceae species. J. Fungi 2020, 6, 1-26, http://dx.doi.org/10.3390/jof6030128.

13. El-Hawary, S.S.; Moawad, A.S.; Bahr, H.S.; Abdelmohsen, U.R.; Mohammed, R. Natural product diversity from the endophytic fungi of the genus Aspergillus. $R S C$ Adv 2020, 10, 22058-22079, http://dx.doi.org/10.1039/d0ra04290k.

14. Ababutain, I.M.; Aldosary, S.K.; Aljuraifani, A.A.; Alghamdi, A.I.; Alabdalall, A.H.; Al-Khaldi, E.M.; Aldakeel, S.A.; Almandil, N.B.; Azeez, S.A.; Borgio, J.F. identification and antibacterial characterization of endophytic fungi from Artemisia sieberi. Int $J$ Microbiol 2021, 2021, 1-11, https://doi.org/10.1155/2021/6651020 
15. Rai, N. Plant associated fungal endophytes as a source of natural bioactive compounds. Mycology 2021, 12, 139-159, http://dx.doi.org/10.1080/21501203.2020.1870579.

16. Singh, A.; Singh, D.K.; Kharwar, R.N.; White, J.F.; Gond, S.K. Fungal endophytes as efficient sources of plant-derived bioactive compounds and their prospective applications in natural product drug discovery: Insights, avenues, and challenges. Microorganisms 2021, 9, 1-42, http://dx.doi.org/10.3390/microorganisms9010197.

17. Adeleke, B.S.; Babalola, O.O. Pharmacological potential of fungal endophytes associated with medicinal plants: A review. J. Fungi 2021, 7, 1-16. http://doi.org/10.3390/jof7020147.

18. Habisukan, U.H.; Elfita; Widjajanti, H.; Setiawan, A.; Kurniawati, A.R. Diversity of endophytic fungi in Syzygium aqueum. Biodiversitas 2021, 22, 1129-1137, http://dx.doi.org/10.13057/biodiv/d220307.

19. Yohandini, H.; Julinar; Muharni. Isolation and phylogenetic analysis of thermophile community within tanjung sakti hot spring, South Sumatera, Indonesia. HAYATI J Biosci 2015, 22, 143-148, http://dx.doi.org/10.1016/j.hjb.2015.10.006.

20. Muharni; Fitrya; Ruliza, M.O.; Susanti, D.A.; Elfita. Di-(2-ethylhexyl)phthalate and pyranon derivated from endophytic fungi Penicillium sp the leave of kunyit putih (Curcuma zedoaria). Indones J Chem 2014, 14, 290-296.

21. Jadhav, N.; Patil, C.R.; Chaudhari, K.B.; Wagh, J.P.; Surana, S.J.; Jadhav, R.B. Diuretic and natriuretic activity of two mistletoe species in rats. Phcog Res 2010, 2, 50-57, http://dx.doi.org/10.4103/09748490.60576.

22. Korespondesi, P.; Maulidar, N.P.; Haro, G. Penetapan kadar kalium, kalsium, natrium dan magnesium dalam bunga nangka (Artocarpus heterophyllus lam.) jantan secara spektrofotometri serapan atom. Media Farm. J. Ilmu Farm 2018, 15, 81-87, http://dx.doi.org/10.12928/mf.v15i2.12659.

23. Tufer, S.; Engidawork, E.; Ayele, A.G.; Bashea, C. Evaluation of the diuretic activity of aqueous and $80 \%$ methanol extracts of Croton macrostachyus (euphorbiaceae) leaves in saline-loaded rats. J Exp Pharmacol 2021, 2021, 213-221, http://dx.doi.org/10.2147/JEP.S294062.

24. Mahmoodpoor, A.; Zahedi, S.; Pourakbar, A.; Hamishehkar, H.; Shadvar, K.; Asgharian, P.; Shahabi, F.; Hamishehkar, H. Efficacy of furosemide-albumin compared with furosemide in critically ill hypoalbuminemia patients admitted to intensive care unit: a prospective randomized clinical trial. $J$ Pharm Sci 2020, 1, 1-7, http://dx.doi.org/10.1007/s40199-020-00339-8.

25. Huyut, Z.; Beydemir, Ş.; Gülçin, I. Antioxidant and antiradical properties of selected flavonoids and phenolic compounds. Biochem Res Int 2017, 2017, 1-10, http://dx.doi.org/10.1155/2017/7616791.

26. Madyastuti, R.; Wientarsih, I.; Widodo, S.; Purwaningsih, E.H.; Harlina, E. The diuretic activity and urin mineral analysis of cat wishker's extract (Orthosiphon stamuneus benth) effect in male rats. Acta Vet Indones 2020, 8, 16-23.

27. Ramadhian, M.R.; Pahmi, K. Aktivitas diuresis Leucaena leucocephala 1. pada mencit jantan (Mus musculus). Journal Syifa Sciences and Clinical Research 2021, 3, 19-28, https://doi.org/10.37311/jsscr.v3i1.9894.

28. Brater, D.C. Diuretic therapy in congestive heart failure. Congest Hear Fail 2000, 6, 197-201, http://dx.doi.org/10.1080/00015385.2021.1878423.

29. Nalwaya, N.; Jarald, E.; Asghar, S.; Ahmad, S. Diuretic activity of a herbal product UNEX. Int J Green Pharm 2009, 3, 224-226.

30. Ding, D. Ototoxic effects and mechanisms of loop diuretics. J Otol 2016, 11, 145-156, http://dx.doi.org/10.1016/j.joto.2016.10.001.

31. Bolda Mariano, L.N. Prolonged diuretic and renoprotective effects of a xanthone obtained from Garcinia achachairu rusby in normotensive and hypertensive rats. Evidence-based Complement Altern Med 2021, 2021, 1-9, http://dx.doi.org/10.1155/2021/5510053.

32. Schlickmann, F. Gallic acid, a phenolic compound isolated from Mimosa bimucronata (DC.) Kuntze leaves, induces diuresis and saluresis in rats. Naunyn Schmiedebergs Arch Pharmacol 2018, 391, 649-655, http://dx.doi.org/10.1007/s00210-018-1502-8.

33. Sarker, M. Diuretic and laxative activities of Kandelia candel and Brownlowia tersa in experimental mice. J Med Plants Stud 2021, 9, 59-65. http://dx.doi.org/10.22271/plants.2021.v9.i2a.1267.

34. Meharie, B.G.; Tunta, T.A. Evaluation of diuretic activity and phytochemical contents of aqueous extract of the shoot apex of Podocarpus falcactus. $J$ Exp Pharmacol 2020, 12, 629-641, http://dx.doi.org/10.2147/JEP.S287277.

35. Jackson, A.M.; Dewan, P.; Anand, I.S.; Bělohlávek, J.; Bengtsson, O.; de Boer, R.A.; Böhm, M.; Boulton, D.W.; Chopra, V.K.; DeMets, D.L.; Docherty, K.F.; Dukát, A.; Greasley, P.J.; Howlett, J.G.; Inzucchi, S.E.; Katova, T.; Køber, L.; Kosiborod, M.N.; Langkilde, A.M.; Lindholm, D.; Ljungman, C.E.A.; Martinez, F.A.; O’Meara, E.; Sabatine, M.S.; Sjöstrand, M.; Solomon, S.D.; Tereshchenko, S.; Verma, S.; Jhund, P.S.; McMurray, J.J.V. Dapagliflozin and diuretic use in patients with heart failure and reduced ejection fraction in dapa-hf. $J \quad A m$ Heart Assoc 2020, 2020, 1040-1054, http://doi.org/10.1161/CIRCULATIONAHA.120.047077. 